\title{
Porcine endometrial and conceptus tissue kallikrein 1, 4, 11, and 14 gene expression
}

\author{
S C Fernando, J S Buck, M D Ashworth, J W Ross, R D Geisert and U DeSilva \\ Department of Animal Science, Oklahoma Agricultural Experiment Station, Oklahoma State University, Animal \\ Science Building, Room 206, Stillwater, Oklahoma 74078, USA \\ Correspondence should be addressed to R D Geisert; Email: geisertr@missouri.edu
}

\begin{abstract}
Previous studies have suggested that the porcine endometrium may express several tissue kallikreins during the estrous cycle and early pregnancy. The present study investigated porcine endometrial and conceptus tissue kallikrein 1, 4, 11, and 14 mRNA expression during the estrous cycle and early pregnancy. Tissue kallikrein $(K L K)$ gene expression was evaluated using quantitative RT-PCR and in situ hybridization. KLK1 expression was similar across the estrous cycle and early pregnancy, and localized to the endometrial luminal $(\mathrm{L})$ and glandular $(\mathrm{G})$ epithelium. $K L K 4$ endometrial mRNA expression was greatest on days 0 , 5, and 10 when compared with days 12, 15, and 17 of the estrous cycle and greater in cyclic compared with pregnant gilts. Expression of $K L K 4$ was more intense in the stroma and uterine epithelium from days 0 to 10 of the estrous cycle. Endometrial $K L K 11$ mRNA was not different between cyclic and pregnant gilts but the expression was greatest on days 10 and 12 compared with all other days evaluated. There was an increased intensity of $K L K 11$ gene expression in the stratum compactum on day 10 of the estrous cycle and early pregnancy. Endometrial KLK14 mRNA expression was not detectable on days 5 and 10 but was expressed on days 0 , 12, 15, and 17 of the estrous cycle and pregnancy. KLK14 expression was localized in the uterine $L$ and $G$ epithelium, and stroma throughout the endometrium after day 10. Conceptus KLK1 mRNA did not change from days 10 to 17 of gestation. However, conceptus $K L K 4$, and 14 mRNA expression was greatest on day 10 with expression declining after day 14 of gestation. Expression of the various tissue kallikreins in the endometrium and conceptus during the estrous cycle and early pregnancy in the pig can serve in the activation of growth factors and tissue remodeling during the establishment of pregnancy.
\end{abstract}

Reproduction (2006) 132 939-947

\section{Introduction}

Prior to initiating the epitheliochorial type of placental attachment to the uterine surface on day 13 of pregnancy, porcine conceptuses undergo rapid elongation from a 10 $\mathrm{mm}$ sphere to a long filamentous thread-like structure (Geisert et al. 1982, Stroband \& Van de Lende 1990). Following trophoblast elongation, attachment to the uterine surface epithelium by the developing conceptuses stimulates a localized increase in transcapillary transport (Keys \& King 1990) and uterine blood flow (Ford et al. 1982), which occurs concurrently with the establishment and maintenance of pregnancy (Geisert \& Yelich 1997). The increase in uterine blood flow and many of the endometrial responses that occur during early porcine conceptus development resembles the acute-phase response induced during tissue inflammation (Salier et al. 1996, Geisert \& Yelich 1997).

The tissue kallikrein family of serine proteases activate a wide range of substrates and growth factors (Chan et al.
1999), suggesting that kallikreins are involved in many integral processes of early embryonic development, such as regulation of uterine blood flow, angiogenesis, tissue invasion, and mitogenesis (Yousef \& Diamandis 2003). Five tissue kallikrein genes have been detected in endometrium of mice and rats and are proposed to play a role in uterine physiological function during embryo implantation (Valdes et al. 1996, Corthorn et al. 1997, Chan et al. 1999). Detection of tissue kallikrein enzymatic activity in the porcine uterine lumen (Vonnahme et al. 1999), as well as the presence of the substrate for tissue kallikrein, low molecular weight (LMW) kininogen, in the porcine endometrium indicates an active kallikrein-kininogen-kinin system exists during early conceptus development and placental attachment (Vonnahme et al. 2004). Indeed, a pregnancy-specific increase in bradykinin release occurs during the period of trophoblast attachment to the uterine surface, indicating involvement of tissue kallikreins in establishment of pregnancy in the pig (Allen et al. 2002). 
Recent studies have demonstrated that uterine tissue kallikreins are involved in the cleavage of insulin-like growth factor binding proteins in the uterine lumen on day 12 in cyclic and pregnant gilts (Geisert et al. 2001), suggesting that several different kallikreins may be present during early conceptus development. The tissue kallikrein family is encoded by a single gene cluster located at porcine chromosome region 6q12-21 (Fernando et al. 2006). Sequence analysis of the tissue kallikrein region revealed the presence of 13 tissue kallikrein genes in the porcine genome. It is possible that the uterine tissue kallikreins may be involved with extracellular matrix remodeling, degradation of insulinlike growth factor binding proteins, and bradykinin release during early conceptus development in the pig (Geisert et al. 1998, 2001). Previous isolation, sequencing, and tissue detection of the porcine tissue kallikrein genes indicated that four genes orthologous to human kallikrein $(K L K) 1,4,11$, and 14 are expressed abundantly in the endometrium (Fernando et al. 2006). Therefore, the present study characterized endometrial and conceptus $K L K 1, K L K 4, K L K 11$, and $K L K 14 \mathrm{mRNA}$ expression during the porcine estrous cycle and early pregnancy.

\section{Materials and Methods}

\section{Animals}

Research was conducted in accordance with the Guiding Principles for Care and Use of Animals promoted by the Society for the Study of Reproduction and approved by the Oklahoma State Institutional Care and Use Committee. Cyclic, crossbred gilts of similar age (8-10 months) and weight (100-130 kg) were checked twice daily for the onset of estrus behavior (estrus onset $=$ day 0 of estrous cycle) using intact boars. Gilts assigned for mating were bred naturally with fertile boars $12 \mathrm{~h}$ after the first detection of estrus onset and again $12 \mathrm{~h}$ later. Cyclic gilts (4 gilts/day) were hysterectomized on either day 0,5 , $10,12,15$, or 17 of the estrous cycle, while pregnant gilts (4 gilts/day) were hysterectomized on either day 10, 12, 15, or 17 as described previously by Gries et al. (1989).

Following initial induction of anesthesia with $1.5 \mathrm{ml}$ intramuscularly administrated cocktail consisting of $2.5 \mathrm{ml}$ Rompum (xylazine; $100 \mathrm{mg} / \mathrm{ml}$; Phoenix Scientific Inc, St. Louis, MO, USA) and $2.5 \mathrm{ml}$ Vetamine (ketamine $\mathrm{HCl} ; 100 \mathrm{mg} / \mathrm{ml}$; Mallickrodt Veterinary, Mundelein, IL, USA) in $500 \mathrm{mg}$ Telazol (tiletamine $\mathrm{HCl}$ and zolazepam $\mathrm{HCl}$; Fort, Dodge, Syracuse, NE, USA), anesthesia was maintained with a closed circuit system of halothane (Halocarbon Laboratories, Riveredge, NJ, USA) and oxygen $(1.0 \mathrm{l} / \mathrm{min})$. The uterus was exposed via mid-ventral laparotomy and the uterus and ovaries were excised. Uterine luminal contents and conceptuses from bred females were flushed from the horn by infusing $20 \mathrm{ml}$ PBS (pH 7.4) through the lumen and collecting flushings into a petri dish. Conceptuses were removed from flushings, snap-frozen in liquid nitrogen and stored at $-80^{\circ} \mathrm{C}$. At hysterectomy, several sections $(\sim 0.5 \mathrm{~cm})$ from the middle of each uterine horn were prepared for in situ hybridization by fixing in fresh $4 \%$ paraformaldehyde in PBS ( $\mathrm{pH} \mathrm{7.2)} \mathrm{and} \mathrm{embedding} \mathrm{in} \mathrm{Paraplast-Plus}$ (Oxford Laboratory, St Louis, MO, USA). Endometrial tissue was removed from the antimesometrial side of the uterine horn, immediately snap-frozen in liquid nitrogen, and stored at $-80^{\circ} \mathrm{C}$ until utilized for RNA extraction. To more closely characterize conceptus kallikrein mRNA expression across the early stages of embryo development, conceptuses were collected from an additional group of gilts (3 gilts/day) hysterectomized on days 11, 13, 14,16 , and 17 of gestation.

\section{RNA extraction from endometrial tissue}

Following addition of $4 \mathrm{ml}$ TRIzol (Invitrogen) to approximately 1 g endometrial tissue, samples were homogenized using a Virtishear homogenizer (Virtis Company, Inc., Gardiner, NY, USA). Samples were incubated at room temperature for $5 \mathrm{~min}$ and $1 \mathrm{ml}$ chloroform was added to the sample, incubated at room temperature for $3 \mathrm{~min}$ and then centrifuged at $4{ }^{\circ} \mathrm{C}$ for $30 \mathrm{~min}$ at $5000 \mathrm{~g}$. The aqueous phase was transferred into a fresh tube, $2.5 \mathrm{ml}$ sopropyl alcohol added, placed in a $-80{ }^{\circ} \mathrm{C}$ freezer for $20 \mathrm{~min}$ and centrifuged at $4{ }^{\circ} \mathrm{C}$ for 30 min at $22500 \mathrm{~g}$. Supernatant was discarded and the pellet was washed with $3 \mathrm{ml}$ of $75 \%$ ethanol and then air-dried for $5 \mathrm{~min}$. Total RNA was resuspended in $500 \mu \mathrm{l}$ diethyl pyrocarbonate (DEPC)treated water and further purified by phenol:chloroform:isoamyl alcohol extraction followed by ethanol precipitation. Samples were treated with DNase I (Invitrogen) according to the manufacture's protocol to eliminate possible DNA contamination. Total RNA was quantified with a spectrophotometer at an absorbance of $260 \mathrm{~nm}$ and purity was verified based on the ratio of 260:280. Integrity of the extracted RNA was further evaluated by electrophoresis, using a fraction of the RNA extract on a $1.0 \%$ agarose denaturation gel containing $1.68 \%$ formaldehyde.

\section{RNA extraction from conceptus tissue (RNAWIZ)}

A tenfold volume of RNAWIZ (Ambion, Austin, TX, USA) was added to 1 volume conceptus tissue and the mixture vortexed until the tissue was completely homogenized. The solution was incubated at room temperature for 5 min, $0.2 \times$ starting volume of chloroform was added to the homogenate, vortexed for $\sim 20 \mathrm{~s}$ and then incubated at room temperature for $10 \mathrm{~min}$. After incubation, sample was centrifuged at $4{ }^{\circ} \mathrm{C}$ for $30 \mathrm{~min}$ at $16000 \mathrm{~g}$, aqueous phase was transferred into a fresh tube, and $0.5 \times$ starting volume of RNase-free water was added and mixed well. Isopropanol $(1 \times)$ was immediately added and sample placed in a $-80{ }^{\circ} \mathrm{C}$ ultralow freezer. Following a 30-min freezing period, the sample was then 
centrifuged at $4{ }^{\circ} \mathrm{C}$ for $15 \mathrm{~min}$ at $16000 \mathrm{~g}$, supernatant discarded and pellet washed with $3 \mathrm{ml}$ of $75 \%$ ethanol. The resulting pellet was resuspended in $50 \mu$ DEPCtreated water and samples treated with DNase I (Invitrogen) according to the manufacture's protocol.

\section{Quantitative real-time PCR}

Quantitative analysis of porcine endometrial and conceptus $K L K 1, K L K 4, K L K 11$, and $K L K 14$ mRNA were conducted using quantitative real-time reverse transcriptase-PCR (qRT-PCR) as previously described (Hettinger et al. 2001). The transcripts for $K L K 1, K L K 4$, and $K L K 14$ were evaluated using dual labeled probes containing 6-Fam ( $5^{\prime}$ reporter dye), and TAMRA ( $3^{\prime}$ quenching dye). Primers and probes for $K L K 1, K L K 4$, and $K L K 14$ (Table 1) were developed from porcine-specific sequences (GenBank AC149292). Quantification of KLK11 (primers presented in Table 1) was evaluated using SYBR green reporter assay kit available from Qiagen. All primers and probes were developed using Primer3 (Rozen \& Skaletsky 2000) and software available at IDT (Integrated DNA Technologies; http://scitools.idtdna.com/Primerquest/) and were designed to cross an intron to prevent genomic DNA amplification. AII PCR products were sequenced to confirm identity of the $K L K$. For qRT-PCR of $K L K 1,4$ and 14 , a total reaction volume of $25 \mu$ l contained $400 \mathrm{nM}$ forward primer, $400 \mathrm{nM}$ reverse primer, $200 \mathrm{nM}$ dual labeled fluorescent probe, $1 \times$ Master mix (Qiagen), $12.5 \mathrm{U}$ RT, and $100 \mathrm{ng}$ total RNA. Thermal cycling conditions were $50{ }^{\circ} \mathrm{C}$ for $30 \mathrm{~min}, 95^{\circ} \mathrm{C}$ for $10 \mathrm{~min}$, followed by 45 additional cycles of $95^{\circ} \mathrm{C}$ for $15 \mathrm{~s}$, and $60{ }^{\circ} \mathrm{C}$ for $1 \mathrm{~min}$. Thermal cycling conditions used for SYBR green detection of $K L K 11$ were $50{ }^{\circ} \mathrm{C}$ for $30 \mathrm{~min}$, $95{ }^{\circ} \mathrm{C}$ for $10 \mathrm{~min}$, followed by 45 additional cycles of $95{ }^{\circ} \mathrm{C}$ for $15 \mathrm{~s}$ and $61{ }^{\circ} \mathrm{C}$ for $30 \mathrm{~s}$, and $72{ }^{\circ} \mathrm{C}$ for $1 \mathrm{~min}$. Ribosomal 18S RNA (18S RNA Control Kit; Eurogenetec, Philadelphia, PA, USA) was assayed according to the manufacturer's protocol for each sample for normalization. The qRT-PCR reactions were performed in an ABI PRISM 7500 sequence detection system (Applied Biosystems, Foster City, CA, USA).
Template amplification was quantified by determining the threshold cycle $\left(C_{\mathrm{T}}\right)$ based on the fluorescence detected within the geometric region of the semi-log plot. Theoretically, in the geometric region, one cycle is equivalent to the doubling of PCR target template. A tenfold dilution series starting from $1 \mu \mathrm{g}$ to $100 \mathrm{pg}$ was made for each assay to determine the actual PCR efficiency and the dynamic range, which resulted in correlation coefficients of 0.982, 0.965, 0.996, and 0.996 for $K L K 1, K L K 4, K L K 11$, and $K L K 14$ respectively. Using the comparative $C_{\mathrm{T}}$ method (Hettinger et al. 2001), relative quantification of mRNA abundance was determined for the endometrial samples. Sample expressions of $K L K 1, K L K 4, K L K 11$, and $K L K 14$ mRNA were normalized with ribosomal $18 \mathrm{~S}$ expression to adjust for sample loading. Relative units of target mRNA expression were calculated by arbitrarily setting the lowest sample measurement $\left(C_{\mathrm{T}}\right)$ as one relative unit, which was utilized as the baseline standard to compare mRNA abundance for all other samples. Relative mRNA abundance was calculated using the PCR efficiencies for $K L K 1, K L K 4, K L K 11$, and $K L K 14$ in the formula $2^{-C_{\mathrm{T}}}$.

\section{In situ hybridization}

In situ hybridizations were performed using digoxigenin (DIG)-labeled cRNA probes using the protocol described by Adelson et al. (2004). PCR primers were designed with the forward primer having the T7 RNA polymerase site incorporated to the $5^{\prime}$ end of the primer, whereas the T3 RNA polymerase site was incorporated to the $5^{\prime}$ end of the reverse primer (Table 2). $K L K 1, K L K 4, K L K 11$, and $K L K 11$ were amplified by RT-PCR as described by Fernando et al. (2006). A DIG RNA Labeling kit (Roche Diagnostics) was used according to the manufacture's protocols to synthesize the sense and antisense RNA from the amplified PCR product. The RNA probes synthesized were quantified and an equal amount of each probe was used for hybridization.

Paraffin-embedded tissue was serially sectioned $(6 \mu \mathrm{m})$ and mounted on positively charged glass microscope slides. The slides were deparaffinized in

Table 1 Porcine PCR primer and probe sequences used for quantitative RT-PCR.

\begin{tabular}{|c|c|c|}
\hline Gene & & Forward primer/reverse primer/probe \\
\hline \multirow[t]{3}{*}{$K L K 1$} & Forward & 5'-GGACTACAGCCACGACСТCATGCTGC-3' \\
\hline & Reverse & 5'-GTCGGGGAATTCGAAGTCGTCTGG-3' \\
\hline & Probe & 5'-TGGAGCTGCCCACCCAGGAACCCGAA-3' \\
\hline \multirow[t]{3}{*}{$K L K 4$} & Forward & 5'-ATCCGCAATGGGTGCTGTCA-3' \\
\hline & Reverse & 5'-GGGTTCTTGTTCGGGCTCAAGATT-3' \\
\hline & Probe & 5'-ATTCCTACACCATCGGGCTGGGTC-3' \\
\hline \multirow[t]{2}{*}{$K L K 11^{\mathrm{a}}$} & Forward & 5'-CGTCCAGCCCCCAGTTG-3' \\
\hline & Reverse & 5’-CCATGGTGTCCGTGATGTTG-3’ \\
\hline \multirow[t]{3}{*}{$K L K 14$} & Forward & 5'-ATGTTCCTCСTGCTGACAGCACT-3' \\
\hline & Reverse & $5^{\prime}$-CAGAGGAAACGATGCCAGGGACC- $3^{\prime}$ \\
\hline & Probe & 5'-GCCACGGCACAGAGCCAGGGCAATGAGAACAAGATAAT-3' \\
\hline
\end{tabular}

\footnotetext{
${ }^{\mathrm{a}}$ Expression of mRNA determined with SYBR green.
} 
Table 2 Porcine PCR primers used for cRNA synthesis for in situ hybridization experiments.

\begin{tabular}{|c|c|}
\hline Gene & Forward primer/reverse primer \\
\hline \multirow[t]{2}{*}{ KLK1 } & 5'-TAATACGACTCACTATAGGGGACTACAGCCACGACCTCATGCTGC-3' \\
\hline & 5'-AATTAACCCTCACTAAAGGCACCCATACAGGTGTCCTTGCCACCT-3' \\
\hline \multirow[t]{2}{*}{$K L K 4$} & 5'-TAATACGACTCACTATAGGGTGGCTTCTGAGGAGGTCTG-3' \\
\hline & 5'-АATTAACССТСАСТАAAGGGССТGGATGGTCGTCTGTAT-3' \\
\hline \multirow{2}{*}{ KLK11 } & 5'-TAATACGACTCACTATAGGTGTCGGGGGAGAGACTAGGA-3' \\
\hline & 5'-ААТTAАСССТСАСТАAAGGCGGCAGTGАСАСАСТGTGAA-3' \\
\hline \multirow[t]{2}{*}{ KLK14 } & 5'-TAATACGACTCACTATAGGATGTTCCTCCTGCTGACAGCACTTCA-3' \\
\hline & 5'-AATTAACCCTCACTAAAGGGTGGGTCCGGGAGTTGTACT-3' \\
\hline
\end{tabular}

xylene and serially rehydrated in $100-50 \%$ ethanol and PBS. The rehydrated slides were digested with proteinase $\mathrm{K}\left(10 \mu \mathrm{g} / \mathrm{ml}\right.$; Invitrogen) for $10 \mathrm{~min}$ at $60^{\circ} \mathrm{C}$. The proteinase K-treated slides were then acetylated at room temperature for $15 \mathrm{~min}$ to minimize background signal. Upon acetylation, the slides were prehybridized in $50 \%$ formamide (Sigma-Aldrich), $2 \times$ SSC, and salmon sperm DNA $(50 \mu \mathrm{g} / \mathrm{ml})$ for $2 \mathrm{~h}$ at $53{ }^{\circ} \mathrm{C}$. The sections were then hybridized with DIG-labeled sense or antisense probes $(5 \mathrm{ng} / \mu \mathrm{l})$ at $53{ }^{\circ} \mathrm{C}$ for $16 \mathrm{~h}$ in the presence of $50 \%$ formamide (Sigma-Aldrich), $4 \times$ SSC, $50 \mu \mathrm{g} / \mathrm{ml}$ yeast tRNA, $1 \times$ Denhardt's solution, and $100 \mathrm{mg}$ dextran sulfate solution. Following hybridization, unbound cRNA probes were removed by washing with $2 \times \mathrm{SSC} / 50 \%$ formamide at $55^{\circ} \mathrm{C}$ for 15 min, digestion with $50 \mu \mathrm{g} / \mathrm{ml}$ RNase A (Invitrogen) at $55{ }^{\circ} \mathrm{C}$ for $30 \mathrm{~min}$ and washing in $1 \times \mathrm{SSC} / 50 \%$ formamide for $10 \mathrm{~min}$ at $55{ }^{\circ} \mathrm{C}$. The sections were then incubated for $2 \mathrm{~h}$ in $1 \%$ DIG-blocking reagent (Roche Diagnostics) and was treated with anti-DIG conjugated with alkaline phosphatase for $60 \mathrm{~min}$ and was visualized using the DIG Nucleic Acid detection Kit (Roche Diagnostics). The endogenous alkaline phosphatase activity was blocked by the addition of $5 \mathrm{mM}$ levamisole chromogenic reagent solution. The color development was stopped by immersing the slides in TE buffer.

\section{Statistical analysis}

Data were analyzed by the least square ANOVA using the PROC MIXED procedure of SAS (1988). The statistical model used to analyze endometrial gene expression $\left(\Delta C_{\mathrm{T}}\right.$ value $)$ included effects of day, reproductive status (cyclic and pregnant), and the day $X$ reproductive status interaction. The fixed effect of day was tested for conceptus $K L K$ mRNA expression. Results are presented as least square means \pm s.E.M.

\section{Results}

\section{Endometrial and conceptus KLK1, KLK4, KLK11, and KLK14 expressions}

Endometrial and conceptus $K L K 1, K L K 4, K L K 11$, and KLK14 mRNA expressions were analyzed using quantitative real-time PCR and in situ hybridization.
Endometrial KLK1 mRNA expression was detected across all days of the estrous cycle and early pregnancy (Fig. 1), but endometrial $K L K 1$ mRNA expression was not effected by day or status $(P<0.10)$. KLK1 expression was localized in the uterine lumenal (L) and glandular (G) epithelium (Fig. 2). Conceptus KLK1 mRNA expression was similar across all days of gestation evaluated (Fig. 4).

Quantitative RT-PCR analysis of endometrial KLK4 mRNA expression (Fig. 1) revealed a significant day $(P<0.05)$ and status $(P<0.01)$ effect on mRNA expression. Endometrial KLK4 mRNA expression was greatest during the early days of the estrous cycle (days 0-10) compared with the later stages (days 12-17) of the estrous cycle and early pregnancy (Fig. 1). Endometrial $K L K 4$ expression was detected in the uterine epithelium and stroma (Fig. 3). The intensity of KLK4 mRNA expression was greatest on days 5-10 of the estrous cycle and early pregnancy. Stromal KLK4 expression was particularly pronounced during the early stages of the estrous cycle with intensity declining after day 10 . However, KLK4 expression continued to be evident in the epithelium and the stratum compactum to day 15 of the estrous cycle and pregnancy. Expression of porcine KLK4 mRNA by the developing conceptuses declined following day 14 of gestation as the lowest expression was detected on day 17 of gestation (Fig. 4).

Endometrial KLK11 mRNA expression was effected by day $(P<0.05)$ but not status (Fig. 1$). K L K 11$ endometrial mRNA was lowest on days 0 and 5 of the estrous cycle. Expression of KLK11 increased 14- and 8-fold on days 10 and 12 of the estrous cycle and pregnancy (Fig. 1). The increase in endometrial $K L K 11$ mRNA was followed by a decline in expression on days 15 and 17. Endometrial $K L K 11$ mRNA expression was detected in the uterine epithelium and stroma (Fig. 3). The intensity of KLK11 expression in the stroma (S) was increased on days 10 and 12 with a clear decline observed on day 17 of the estrous cycle and pregnancy. Expression of porcine KLK11 mRNA by the developing conceptuses was approximately four- to five-fold greater $(P<0.05)$ prior to and during the period of trophoblast elongation on day 12. Conceptus $K L K 11$ expression significantly $(P<0.05)$ declined after day 16 of gestation (Fig. 4).

Expression of KLK14 mRNA was not detected in days 5 and 10 cyclic or day 10 pregnant endometrium after 40 

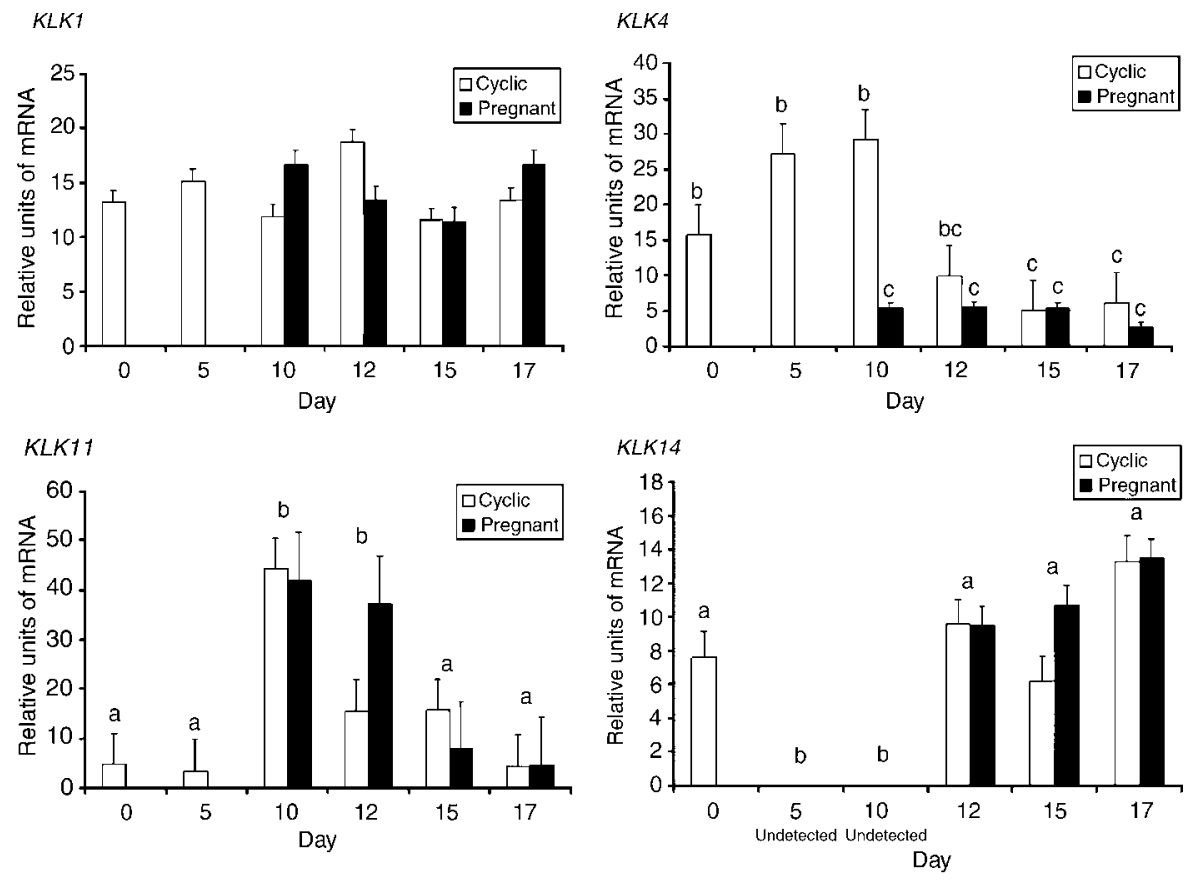

Figure 1 Relative units (mean \pm s.E.M.) of mRNA expressions for endometrial $K L K 1$, $K L K 4, K L K 11$, and $K L K 14$ during the porcine estrous cycle (white bar) and early pregnancy (black bar). Abundance of mRNA was calculated from the real-time PCR analysis as described in Materials and Methods. Bars with different superscripts represent a statistical difference in day $(P<0.001)$.

cycles of qRT-PCR. A day effect $(P<0.01)$ was detected for endometrial $K L K 14$ mRNA as endometrial $K L K 14$ mRNA expression was detected on days $0,12,15$, and 17 (Fig. 1). Endometrial KLK14 mRNA expression was not different between cyclic and pregnant gilts from days 10 to 17 . Expression of KLK14 was not evident in the endometrium of gilts collected on days 5 and 10 of the estrous cycle and day 10 of pregnancy (Fig. 3). Endometrial KLK14 mRNA expression was detected in the uterine $\mathrm{L}$ and $\mathrm{G}$ epithelium and $\mathrm{S}$ stratum compactum from days 12 to 17 of the estrous cycle and pregnancy. Quantitative RT-PCR analysis of conceptus $K L K 14$ mRNA expression revealed a day effect

\section{$K L K 1$}

Day 15 Cyclic

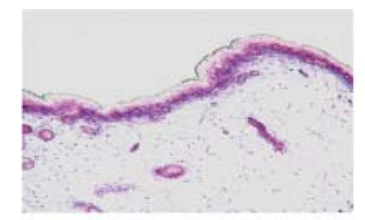

Day 15 Cyclic
Day 17 Pregnant

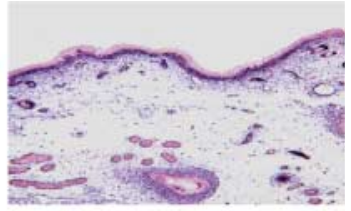

Day 17 Pregnant
Negative

Controls

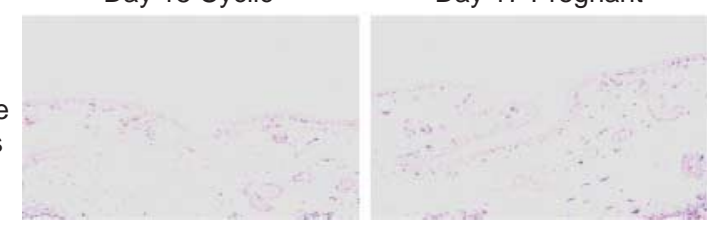

Figure 2 In situ hybridization analysis of $K L K 1$ mRNA expression in porcine endometrium during day 15 of the estrous cycle and day 17 of pregnancy. A representative section of day 15 cyclic and day 17 pregnant endometrium was hybridized with DIG-labeled cRNA probe (sense) to serve as a negative control (L, lumenal epithelium; G, glandular epithelium; and S, stroma). Magnification $\times 260$.
$(P<0.05)$ as expression of $K L K 14$ mRNA declined fourfold after day 16 gestation (Fig. 4).

\section{Discussion}

The role of the various tissue kallikreins in altering extracellular matrix suggests that the serine proteases are involved with uterine implantation and early conceptus development in the pig. Tissue kallikreins are proposed to be involved with the invasive implantation and conceptus development in the rat (Corthorn \& Valdes 1994, Valdes et al. 1996) and mouse (Chan et al. 1999). The tissue kallikreins belong to a large gene family in which 25 members ( 14 genes that encode for serine proteases and 11 are pseudogenes) are present in the mouse, 13 in the rat, and the human kallikrein family consists of 15 genes (Yousef \& Diamandis 2003, Diamandis et al. 2004). The 13 porcine tissue kallikrein genes are clustered on chromosome 6 (Ferando et al. 2006) and the pig lacks orthologs to human KLK2 and KLK3 as occurs in rodents (Yousef \& Diamandis 2003). Tissue kallikreins are known to regulate the activation of many growth factors and extracellular proteases in a variety of tissues (Clements 1997). Expression for a number of the tissue kallikreins is regulated by androgens and estrogens, which contributes to tissue kallikrein expression in reproductive organs including the ovary, uterus, placenta, and mammary gland (Yousef \& Diamandis 2001). Although tissue kallikreins have long been utilized as biomarkers for human prostatic, ovarian, and breast cancer (Yousef \& Diamandis 2003), the specific roles for a number of the various kallikreins is largely unknown. Chan et al. (1999) detected expressions of Klk1,KIk3,Klk9, and Klk21 in 


\section{$K L K 4$}
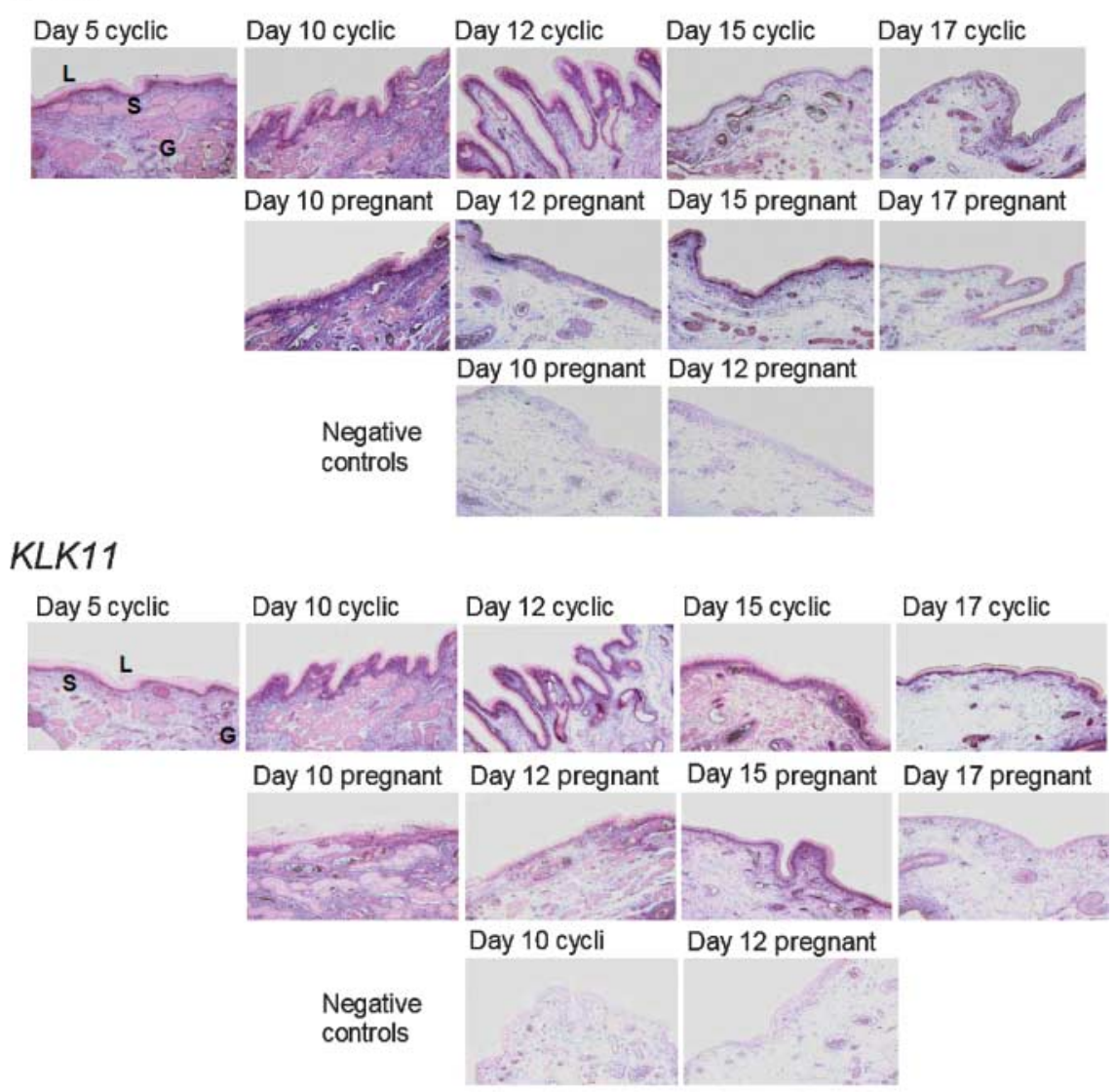

\section{$K L K 14$}

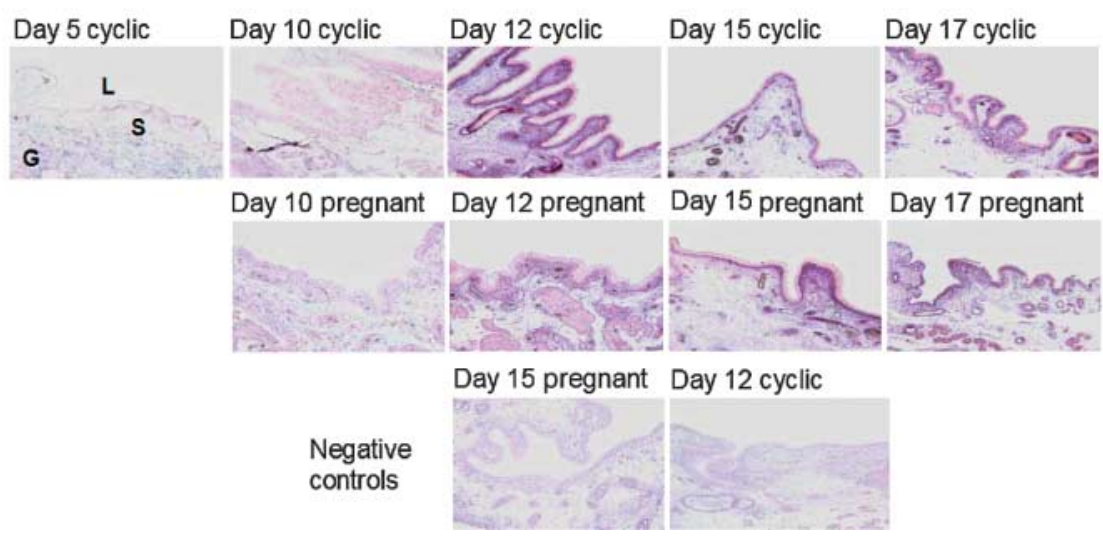

Figure 3 In situ hybridization analysis of $K L K 4$, $K L K 11$, and $K L K 14$ mRNA expression in porcine endometrium during the estrous cycle (C) and pregnancy $(\mathrm{P})$. Protected transcripts in endometrium from days 5, 10, 12, 15, and 17 of the estrous cycle and days 10,12, 15, and 17 of pregnancy were detected using DIGlabeled CRNA probes and were visualized using anti DIG alkaline phosphatase conjugate and a NBT/BCIP substrate. A DIG-labeled sense CRNA probe (Sense) was used as a negative control ( $L$, lumenal epithelium; G, glandular epithelium; and S, stroma). Magnification $\times 260$.

early mouse embryos and $K I k 1$ and $K I k 21$ mRNA expressions in the endometrium and decidua during pregnancy. Porcine endometrial expressions of $K L K 1$, KLK4, KLK6, KLK9, KLK10, KLK11, KLK14, and KLK15 were detected by RT-PCR (Fernando et al. 2006). However, endometrial expressions of $K L K 4, K L K 9, K L K 11$, and $K L K 14$ were particularly abundant in comparison with other tissues of body. The results of our study indicated that there is differential expression pattern for the four tissue kallikrein genes in the porcine endometrium during the estrous cycle and early pregnancy.
Functionally, KLK1 is considered the major tissue kallikrein serine protease, which liberates bradykinin from LMW-kininogen (Clements 1997). In the rat, the greatest increase in tissue kallikrein is seen in the uterine glandular epithelium (Valdes et al. 1996) and gene expression coincides with the period of trophoblast invasiveness (Chan et al. 1999). Endometrial levels of $K L K 1$ are also increased during the proliferative phase of the human menstrual cycle, which suggests estrogen regulation of the KLK1 gene (Clements et al. 1994). We have previously detected endometrial KLK1 mRNA 

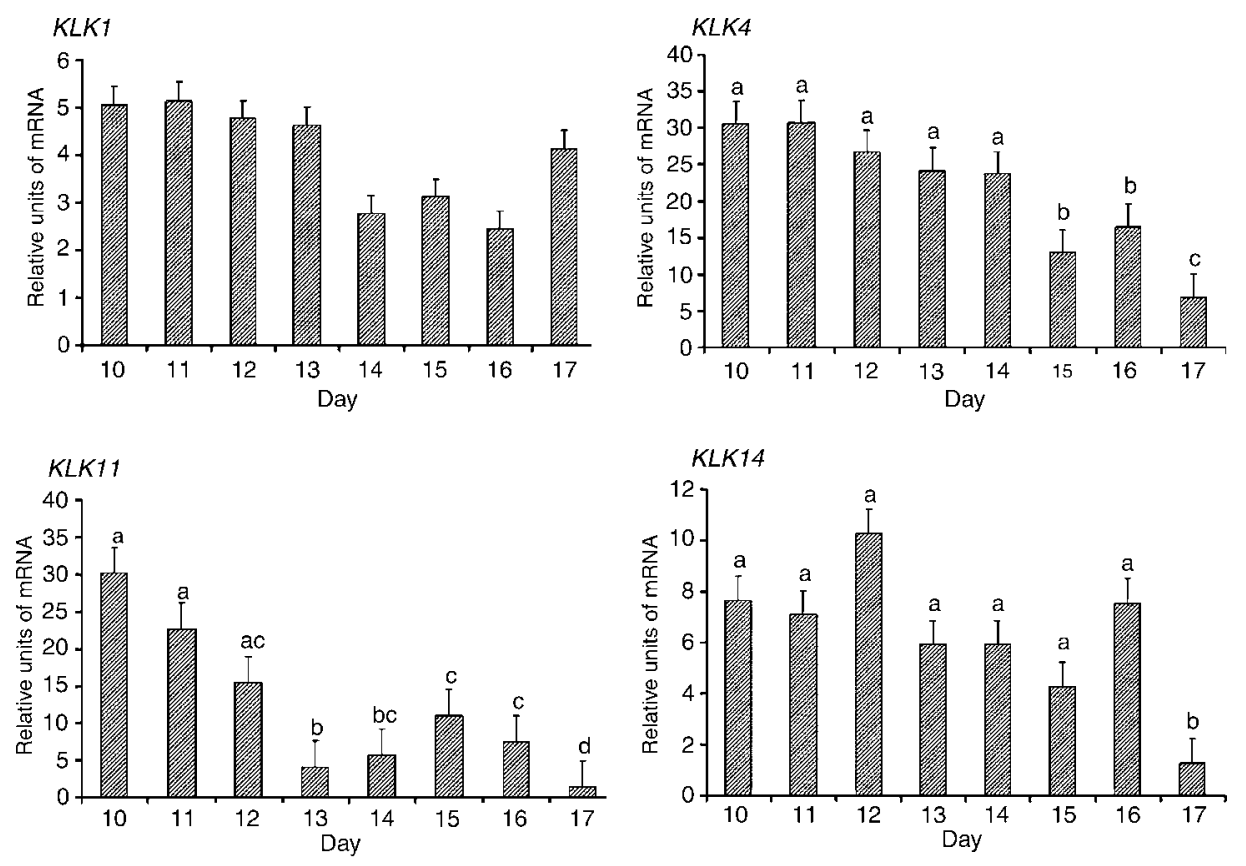

Figure 4 Relative units (mean \pm s.E.M.) of
mRNA expressions for conceptus $K L K 1$,
$K L K 4, K L K 11$, and $K L K 14$ during early
pregnancy. Abundance of mRNA was
calculated from the real-time PCR
analysis as described in Materials and
Methods. Bars with different super-
scripts represent a statistical difference
in day $(P<0.001)$.

and protein expression during early pregnancy in the pig (Vonnahme et al. 1999). KLK1 enzymatic activity, which LMW kininogen is one of its specific substrates to release bradykinin, increases after day 12 of the porcine estrous cycle and early pregnancy (Allen et al. 2002). Although there is an increase in bradykinin release during early pregnancy, endometrial and conceptus expression of KLK1 does not change across the days of the estrous cycle and early pregnancy (Vonnahme et al. 1999, present study). It is possible that conceptus induction of bradykinin release within the uterine lumen may occur through the cleavage of plasma prekallikrein by Factor XII (Vonnahme et al. 2004) rather KLK1. However, gene expression of endometrial plasma kallikrein is very low and not detectable in the conceptus. Detection of $K L K 1$ expression in the uterine $L$ and $G$ epithelium suggests that KLK1 secreted into the uterine lumen could be activated through cleavage by conceptus proteases during attachment to the uterine surface. However, the pregnancy-specific increase of bradykinin release in the uterine lumen needs to be determined.

The present study clearly indicates there is a differential expression of the three other endometrial tissue kallikreins across the days of the estrous cycle and early pregnancy in the pig. Although KLK4 is a secreted serine protease, also known as prostate and/or enamel matrix serine protease, it has a unique structure and function compared with other kallikrein family members (Korkmaz et al. 2001). This serine protease was first identified from the epithelial tissue of developing teeth. In the porcine dental enamel, $K L K 4$ is expressed during early transition and maturation stages of enamel formation where KLK4 participates in the degradation of enamel proteins such as amelogenin (Ryu et al. 2002). Expression of KLK4 is up-regulated by estrogen and progesterone in the human endometrial cancer cell line, KLE (Myers \& Clements 2001). The ability of KLK4 to cleave a broad range of peptides and its localization in the porcine uterine epithelium and strong expression in the stroma on days 0,5 , and 10 estrous cycle and day 10 of pregnancy suggests that, KLK4 may play a role in cellular growth and extracellular matrix remodeling before conceptus attachment to the uterine surface.

Conceptus KLK4 expression is greatest on days 10-13 compared with days 15-17 of conceptus development. This time period is consistent with the time the porcine conceptus starts cell proliferation and placental membrane formation, which suggests that KLK4 may be one of the factors assisting with conceptus extracellular matrix degradation, cellular remodeling, and attachment to the uterine lumenal epithelium during embryonic development in the pig.

Kallikrein 11, previously referred to as hippostasin from its previous isolation from the human hippocampus is another of the tissue kallikreins that is highly expressed in the prostate epithelium and is proposed to be under steroid regulation (Stavropoulou et al. 2005). Since KLK11 is proposed to function as a trypsin-like protease, it may function in the plasticity of the extracellular matrix and/or cleavage of proteins (Mitsui et al. 2000). The pattern of porcine endometrial KLK11 mRNA expression was different from the other three tissue kallikreins investigated in our study. The increase of endometrial KLK11 mRNA in the uterine epithelium and especially the stroma on days 10 and 12 is temporally associated with the time of rapid conceptus development 
and establishment of pregnancy in the pig. However, the increase in endometrial KLK11 mRNA is independent of the presence of conceptuses. Conceptus KLK11 gene expression decreased following trophoblast elongation (day 12) and initiation of uterine attachment. Endometrial KLK11 mRNA also decreased following day 12 indicating a very precise regulation of KLK11 expression during the establishment of pregnancy in the pig.

Endometrial mRNA expression of KLK14 is the most dynamic of any of the tissue kallikreins we evaluated in the porcine uterus. Endometrial KLK14 mRNA expression was not detected on days 5 and 10 of the estrous cycle and early pregnancy. Although previous studies of KLK14 have indicated that the expression is regulated through androgens and estrogens (Borgono et al. 2003, Yousef et al. 2003), our data suggest that $K L K 14$ mRNA expression may be negatively regulated by the presence of progesterone receptor (PR) in the uterine epithelium. Absence of endometrial KLK14 mRNA expression on days 5 and 10 estrous cycle and early pregnancy in the pig is temporally associated with the presence and activation of uterine epithelial PR. During the porcine estrous cycle and early pregnancy, progesterone stimulates the myometrium, stroma, and uterine epithelium through its receptor. However, following approximately $8-10$ days of progesterone stimulation there is a cell-specific loss of PR expression from porcine uterine $L$ and $G$ epithelium on day 12 of the estrous cycle or pregnancy (Geisert et al. 1994). The strong expression of KLK14 in the $\mathrm{L}$ and $\mathrm{G}$ epithelium of the uterus after day 10 of the estrous cycle and early pregnancy suggests that progesterone may inhibit $K L K 14$ mRNA expression in uterine epithelium through progesterone activation of PR in the early stages of the estrous cycle. Human KLK14 has trypsin- and chymotrypsin-like activity (Felber et al. 2005) for which components of the extracellular matrix, laminin $\alpha-5$ and collagen IV, are potential substrates of KLK14. It is possible that the increase in KLK14 mRNA could function in uterine remodeling during establishment of pregnancy in the pig. The spatiotemporal expressions of $K L K 11$ and KLK14 were also consistent with the release of many endometrial cytokines (Geisert \& Yelich 1997) and cleavage of the IGFBPs present in the uterine lumen of the pig (Geisert et al. 2001). The increase in endometrial KLK11 and KLK14 expression during a critical stage of porcine conceptus development suggests that these tissue kallikreins could serve to activate many factors involved with the establishment of pregnancy the pig.

\section{Acknowledgements}

This project was supported by the National Research Initiative Competitive Grant 2002-35203-12262 from the USDA Cooperative State Research, Education, and Extension Service and the Oklahoma Agriculture Experiment Station project
$\mathrm{H}-02465$. Manuscript approved for publication by the Director, Oklahoma Agricultural Experiment Station, Hatch Project OKL02465. Authors thank the Oklahoma State University Recombinant DNA/Protein Resource Facility for the sequencing of CDNA and Mr Steve Welty for the care and feeding of the animals utilized in the study. The authors declare that there is no conflict of interest that would prejudice the impartiality of this scientific work.

\section{References}

Adelson DL, Cam U, Desilva U \& Franklin IR 2004 Gene expression in sheep skin and wool (hair). Genomics 83 95-105.

Allen MR, Zhang BR, Hettinger AM, Goad DW, Malayer JR \& Geisert RD 2002 Detection of bradykinin and bradykinin- $\beta_{2}$ receptors in the porcine endometrium during the estrous cycle and early pregnancy. Biology of Reproduction 66 574-579.

Borgono CA, Grass L, Soosaipillai A, Yousef GM, Petraki CD, Howarth DHC, Fracchioli S, Katsaros D \& Diamandis EP 2003 Human kallikrein 14: a new potential biomarker for ovarian and breast cancer. Cancer Research 63 9032-9041.

Chan CS, Harvey MB \& Clements JA 1999 Temporal and tissue-specific expression of kallikrein ( $\mathrm{klk}$ ) genes and identification of a novel klk messenger ribonucleic acid transcript during early development in the mouse. Biology of Reproduction 61 621-628.

Clements J 1997 The molecular biology of the kallikreins and their roles in inflammation. In The Kinin System, pp 71-97. Ed. S Farmer. New York: Academic Press.

Clements J, Mukhtar A, Ehrlich A \& Yap B 1994 Glandular kallikrein gene expression in the human uterus. Brazilian Journal of Medical and Biological Research 27 1855-1863.

Corthorn J \& Valdes G 1994 Variations in uterine kallikrein during cycle and early pregnancy in the rat. Biology of Reproduction $\mathbf{5 0}$ 1261-1264.

Corthorn J, Figueroa C \& Valdes G 1997 Estrogen and luminal stimulation of rat uterine kallikrein. Biology of Reproduction $\mathbf{5 6}$ 1432-1438.

Diamandis EP, Yousef GM \& Olsson AY 2004 An update on human and mouse glandular kallikreins. Clinical Biochemistry 37 258-260.

Felber LM, Borgono CA, Cloutier SM, Kundig C, Kishi T, Ribeiro Chagas J, Jichlinski P, Gygi CM, Leisinger HJ, Diamandis EP \& Deperthes D 2005 Enzymatic profiling of human kallikrein 14 using phage-display substrate technology. Biological Chemistry $\mathbf{3 8 6}$ 291-298.

Fernando SC, Najar FZ, Guo X, Zhou L, Fu Y, Geisert RS, Roe BA \& DeSilva U 2006 Porcine tissue kallikrein gene family: genomic structure, mapping and differential expression analysis. Genomics [Inpress].

Ford SP, Christenson RK \& Ford JJ 1982 Uterine blood-flow and uterine arterial, venous and luminal concentrations of estrogens on days 11 , 13 and 15 after estrus in pregnant and nonpregnant sows. Journal of Reproduction and Fertility 64 185-190.

Geisert RD \& Yelich JV 1997 Regulation of conceptus development and attachment in pigs. Journal of Reproduction and Fertility Supplement 52 133-149.

Geisert RD, Brookbank JW, Roberts RM \& Bazer FW 1982 Establishment of pregnancy in the pig. II. Cellular remodeling of the porcine blastocyst during elongation on day 12 of pregnancy. Biology of Reproduction 27 941-955.

Geisert RD, Pratt TN, Bazer FW, Mayes JS \& Watson GH 1994 Immunocytochemical localization and changes in endometrial progestin receptor protein during the porcine oestrous cycle and early pregnancy. Reproduction Fertility and Development 6 749-760. 
Geisert RD, Yelich JV, Pratt T \& Pomp D 1998 Expression of an interalpha-trypsin inhibitor heavy chain-like protein in the pig endometrium during the oestrous cycle and early pregnancy. Journal of Reproduction and Fertility 114 35-43.

Geisert RD, Chamberlain CS, Vonnahme KA, Malayer JR \& Spicer LJ 2001 Possible role of kallikrein in proteolysis of insulin-like growth factor binding proteins during the estrous cycle and early pregnancy in pigs. Reproduction 121 719-728.

Gries LK, Geisert RD, Zavy MT, Garrett JE \& Morgan GL 1989 Uterine alterations coincident with embryonic mortality in the gilt after exogenous estrogen administration. Journal of Animal Science 67 276-284.

Hettinger AM, Allen MA, Zhang BR, Goad DW, Malayer JR \& Geisert RD 2001 Presence of acute phase protein, bikunin, in the endometrium of gilts during estrous cycle and early pregnancy. Biology of Reproduction 65 507-513.

Keys JL \& King GJ 1990 Microscopic examination of porcine conceptus-maternal interface between days 10 and 19 of pregnancy. American Journal of Anatomy 188 221-238.

Korkmaz KS, Korkmaz CG, Pretlow T \& Saatcioglu F 2001 Distinctly different gene structure of KLK4/KLK-L1/prostase/ARM1 compared with other members of the kallikrein family: intracellular localization, alternative cDNA forms, and regulation by multiple hormones. DNA and Cell Biology 7 435-445.

Mitsui S, Yamada T, Okui A, Kominami K, Uemura H, \& Yamaguchi N 2000 A novel isoform of a kallikrein-like protease, TLSP/hippostasin, (PRSS20), is expressed in the human brain and prostate. Biochemical and Biophysical Research Communicatons 272 205-211.

Myers SA \& Clements JA 2001 A new member of the human kallikrein gene family is upregulated by estrogen and progesterone in the human endometrial cancer cell line, KLE. Journal of Clinical Endocrinology and Metabolism 86 2323-2326.

Rozen S \& Skaletsky HJ 2000 Primer3 on WWW for general users and for biologist programmers. In Bioinformatics Methods and Protocols: Methods in Molecular Biology, pp 365-386. Eds S Krawetz \& S Misener. Totowa, NJ: Humana Press.

Ryu OH, Hu JCC, Yamakoshi Y, Villemain JL, Cao X, Zhang $\mathbf{C H}$ Bartlett JD \& Simmer JP 2002 Porcine kallikrein-4 activation, glycosylation, activity, and expression in prokaryotic and eukaryotic hosts. European Journal of Oral Sciences 110 358-365.
Salier JP, Rouet P, Raguenez G \& Daveau M 1996 The inter-alphainhibitor family: from structure to regulation. Biochemical Journal $3151-9$.

SAS 1988 SAS User's Guide: Statistics (version 5.0), Cary, NC: Statistical Analysis System Institute Inc.

Stavropoulou P, Gregorakis AK, Plebani M \& Scorilas A 2005 Expression analysis and prognostic significance of human kallikrein 11 in prostate cancer. Clinica Chimica Acta 357 190-195.

Stroband HWJ \& Van der Lende T 1990 Embryonic and uterine development during early pregnancy in pigs. Journal of Reproduction and Fertility Supplement 40 261-277.

Valdes G, Figueroa CD \& Corthorn J 1996 Temporospatial changes of kallikrein-like enzymes during the estrous cycle and pregnancy in the rat uterus. Biology of Reproduction 55 236-245.

Vonnahme KA, Malayer JR, Spivey HO, Ford SP, Clutter A \& Geisert RD 1999 Detection of kallikrein gene expression and enzymatic activity in porcine endometrium during the estrous cycle and early pregnancy. Biology of Reproduction 61 1235-1241.

Vonnahme KA, Fernando SC, Ross JW, Ashworth MD, DeSilva U, Malayer JR \& Geisert RD 2004 Porcine endometrial expression of kininogen, factor XII, and plasma kallikrein in cyclic and pregnant gilts. Biology of Reproduction 70 132-138.

Yousef GM \& Diamandis EP 2001 The new human tissue kallikrein gene family: structure, function, and association to disease. Endocrine Reviews 22 184-204.

Yousef GM \& Diamandis EP 2003 An overview of the kallikrein gene families in humans and other species: emerging candidate tumour markers. Clinical Biochemistry 36 443-452.

Yousef GM, Francis MJ, Scorilas A, Borgono CA, Iskander L, Puopolo M, Massobrio M, Diamandis EP \& Katsuma S 2003 Steroid hormone regulation and prognostic value of the human kallikrein gene 14 in ovarian cancer. American Journal of Clinical Pathology 119 346-355.

Received 20 October 2005

First decision 6 December 2005

Revised manuscript received 2 June 2006

Accepted 3 August 2006 